\title{
New developments in the pathology of malignant lymphoma. A review of the literature published from January 2012-July 2012
}

\author{
J. Han van Krieken
}

Published online: 11 August 2012

(C) Springer-Verlag 2012

\section{Introduction}

This is the 12th article in this series of literature reviews. Obviously, there are topics that have had a lot of attention, like IgG4 disease and breast implant associated large anaplastic T-cell lymphoma (ALCL) and topics that seem not to fly, like the finding that half of the Hodgkin lymphomas (HL) recurrences are actually new lymphomas. It is not so easy to understand why some topics are taken up and others disappear. It is also interesting to see how old findings can be renewed and by publishing them in a high-impact journal start a whole new series of repetitions, like the prognostic impact of macrophages in HL. More and more it seems to me that we are making progress, but not along a straight line. How to measure this progress? Since we do all our research ultimately to benefit our patients (at least that is what drives me) outcome of lymphomas is the best indicator. And there we do well: survival has increased overall and also for most lymphoma types. And this progress is build on the better understanding of the pathogenesis of lymphoma, the detailed description of the epidemiology, the development of new drugs and also, it is my firm belief, thanks to the better definition for entities and the improved classification of lesions by pathologists. I hope this series of literature reviews brings the new knowledge to every interested (hemato)pathologist. It is a personal selection of articles, some from high impact journals, some from low-impact journals, based on results that in my opinion are relevant to pathologists who are involved diagnosing lymphomas. Some of the information is of immediate interest, other work may become relevant for routine practice in the future (or

\section{J. H. van Krieken $(\triangle)$}

Department of Pathology,

Radboud University Nijmegen Medical Centre,

P.O. Box 9101, 6500 Nijmegen, The Netherlands

e-mail: J.vankrieken@pathol.umcn.nl maybe never). Obviously, the majority of paper on lymphomas is not selected, not because they are not good, but just because I did not feel that they were interesting enough for the readers. But of course I may have missed your very interesting article. If that is the case, please let me know and I will include it next time!

\section{Biology of lymphoma}

Hodgkin lymphoma

Already for a long time it is felt that HL has an infectious background. Quite some cases are Epstein-Barr virus (EBV) positive, but why most individuals that are infected with EBV do not develop HL is not clear. HL that are negative for EBV, which is more than half of the nodular sclerosis (NS) subtype, were studied for human herpesvirus 6 (HHV-6) by Siddon et al. [1]. Using polymerase chain reaction (PCR), they found that most reactive lymph nodes are positive for HHV-6 and thus they used immunohistochemstry and fluorescent in situ hybridization (FISH) to see whether the virus is specifically present in Reed-Sternberg cells. They were able to show by dual staining that in almost $50 \%$ of NSHD the CD30-positive cells contain HHV-6 and confirmed this by PCR after laser capture dissection. Positive cells were predominantly found in younger patients whose lymphoma was EBV negative. Further work is needed to understand what this finding really means. At this point, it is not relevant to try to detect this virus in HL for diagnostic purposes.

Several molecular pathways are altered in HL tumor cells. In contrast to most B-cell lymphomas, the tumor cells in 31 out 32 classic HL cases and 14 out 20 cases of nodular lymphocyte predominant HL do not express FOXO1, a transcription factor that controls proliferation and apoptosis 
[2]. Because there are multiple mechanisms that inactivate FOXO1 in HL cell lines, Xie at al. conclude that FOXO1 is a tumor suppressor-gene in HL [2]. So far, there are no drugs available that target this gene, but since it is under control of the PI3 kinase pathway, it might be targeted by upstream proteins. One such an upstream agent is PI3Kdelta (CAL-101), which has according to Meadows et al. [3] effect in HL lines indeed. It induces apoptosis en reduces cell viability. Clinical studies are now suggested.

\section{B-cell lymphomas}

It has become more and more clear that tumor cells alone are helpless creatures that need support from stromal cells to survive. Already for a long time, it is known that follicular lymphomas (FL) invariably have support from dendritic and T-cells. Guiloton et al. [4] took mesenchymal stromal cells from patients with FL and compared their gene expression profile with that of age-matched controls. Several genes that indicate lymphoid commitment are upregulated, especially CCL2. The authors suggest that targeting the stromal cells rather than the tumor cells may be an interesting therapeutic approach. Indeed, if this would be possible, resistance for the drug might be less of a problem, but of course tumor cells might develop independence from (some of the) signals from the stromal cells.

Direct targeting of tumor cells remains the mainstream approach and thus de detection of a target in specific tumor types is an important issue. EZH2 codon 641 mutations are described in several germinal center derived lymphomas. Ryan et al. [5] developed a relatively simple method to determine the presence of this mutation and found EZH2 mutations in 12/55 (22\%) FL, 5/35 (14 \%) diffuse large B cell lymphomas with a germinal center immunophenotype (GCB-DLBCL), and 2/11 (18\%) high-grade B cell lymphomas with concurrent rearrangements of BCL2 and MYC. No EZH2 mutations were detected in cases of Burkitt lymphoma (BL; 0/23). EZH2 mutations were frequently associated with the presence of BCL2 rearrangement (BCL2-R) in both the FL ( $28 \%$ of BCL2-R versus $0 \%$ of BCL2-WT cases, $p<0.05)$ and GCB-DLBCL groups (33\% of BCL2-R cases versus $4 \%$ of BCL2-wild-type cases, $p<0.04$ ), and across all lymphoma types excluding BL ( $27 \%$ of BCL2-R cases versus $3 \%$ of BCL2-WT cases, $p<0.003)$. They conclude that EZH2 mutations are an additional genetic "hit" in many BCL2-R germinal center B cell lymphomas and that these patients may benefit from pharmacologic agents targeting EZH2 and EZH2-regulated pathways.

The steps that lead from gastritis to gastric mucosa associated tissue lymphoma (MALT-L) are not completely clear. Thorns et al. [6] compared the mi-RNA signature of gastritis with MALT-L and found relevant differences for five
miRNAs. One wonders whether the $t(11 ; 18)$ which seems to indicate a different category of MALT-L is related to this signature or not. Another association might be interesting too. Troch et al. [7] looked at the MALT-L biopsies from patients who were treated with rituximab. Since this antibody targets CD20, which is lacking on plasma cells, it is no surprise that after treatment, those patients that did not respond completely had plasma cell differentiation of lymphoma cells in the biopsy after treatment. This could however not be predicted on pretreatment biopsies since in their series of 21 , patients plasma cell differentiation was rare at diagnosis. It is not known whether their finding is due to sampling or that treatment might induce the plasma cell differentiation.

Although the pathogenesis of $\mathrm{BL}$ is one of the best known among lymphomas there are still crucial questions open. In endemic areas most individuals encounter EBV and malaria, known factors, but few develop BL. Mannucci et al. [8] investigated the effect of extracts of the plant Euphorbia tirucalli on EBV-infected cells from healthy individuals. This plant has the same geographical distribution as BL and the extracts indeed led to reactivation of EBV and also to chromosomal aberrations. It is not known yet whether individuals with BL have higher exposure to this plant and it is too early to draw firm conclusions. But our best chances to improve outcome of course is prevention, which might ultimately be dependent on environmental factors.

\section{T-cell lymphoma}

As mentioned in the "Introduction" section, breast implantassociated ALCL is a hype, and this review gives some further quite important new data. Personally, I witnessed the potential danger of a hype. I saw a case that was signed out as breast implant-associated ALCL but was actually a classic ALCL in the breast of a woman with also breast implants. The difference was actually quite obvious: the tumor was not close to the implant, it was a lump about $2 \mathrm{~cm}$ large, at least $1 \mathrm{~cm}$ from the implant; the morphology was a more classic one with lots of inflammatory cells intermingled and there was widespread disease, including liver metastases upon biopsy. I guess such cases will be presented in the workshop in Lisbon as well. The notion I had that this lesion is always indolent seems however to be refuted by the series of 13 cases from Aladily et al. [9]. Their patient age ranged from 39 to 68 years, and the interval from implant to ALCL was 4-29 years. All tumors were composed of large, pleomorphic cells that were CD30 and ALK1 positive, and all seven cases assessed had monoclonal T-cell receptor $\gamma$-chain rearrangements. All patients presented with effusion surrounded by fibrous capsule and in three, there was in addition a grossly identifiable tumor mass. The patients without a mass were all well, regardless 
of therapy. The three patients with a distinct mass adjacent to the implant were a bit different: One patient had a 3-year history of lymphomatoid papulosis and one patient had a 1year history of CD30 T-cell lymphoma adjacent to the breast before the diagnosis of ALCL associated with breast implant. Two patients died 2 and 12 years after diagnosis, respectively. The authors conclude that the clinical behavior of ALCL associated with breast implants is heterogeneous. However, in my opinion, the three patients with a mass and a different history are not to be included in this category, like the patient I described. I expect this to be discussed in Lisbon and hopefully we will come to consensus so that indolent disease can be well defined and unnecessary treatment omitted. It remains questionable therefore whether we need systemic therapy for breast implant associated ALCL. Lechner et al. [10] nevertheless aimed at identifying a target for therapy. They found activation of the STAT-3 signaling pathway in three cell lines from patient biopsies and were able to kill the cells by STAT3 inhibition. Maybe treatment is not really needed for patients with this disease, but the cell lines will certainly give us insight in the pathogenesis of this intriguing disease.

ALK-positive ALCL can be treated quite well, with different approaches, including targeting the ALK protein. Nevertheless, there is need for improvement since resistance occurs. Wang et al. [11] were able to identify another target based on their discovery that ALK-positive ALCL expresses, surprisingly, the embryonic stem cell marker SALL4. This protein is a transcription factor that is crucial in maintaining pluropotency, yet ALCL cells are mature Tcells. They were able to show that the NMP-ALK fusion protein caused the expression and they could also demonstrate that knocking down this gene resulted in apoptosis and cell cycle arrest. In fact, I find the most remarkable finding that one can have stem cell properties in differentiated cells, a concept that is difficult to understand since we associate stemness and differentiation generally as mutually exclusive.

Another relevant altered pathway was found by analyzing cell lines and biopsies from children with ALK+ ALCL using rt-PCR and immunohistochemistry. The PI3K/Akt pathway appeared to be activated in many, though not all, pediatric ALK+ ALCL. Pharmacologic inhibition of activated ALK does not reduce activated Akt. Therefore, therapy of ALCL might become, in the future, a combination of targeting ALK and Akt [12].

\section{Epidemiology of lymphoma}

It is well known that huge regional difference exist for incidences of lymphoma types. These might be genetic or environmental and can teach us a lot on pathogenesis.
Population-based studies are an important tool in the further understanding of factors that contribute to the development of lymphomas. Ai et al. [13] looked a bit deeper, by analyzing not only the incidence but also the clinical behavior of extranodal NK/T-cell lymphoma, nasal type (EN-NK/TL), an entity known for its association with EBV and large regional differences. In California, the incidence rates in non-Hispanic whites, Hispanics and APIs were 0.05, 0.18, and 0.23 per 100,000 person-years, respectively, among males and $0.03,0.07$, and 0.10 per 100,000 person-years, respectively, among females. The overall survival at 5 years was $28.6 \%$ in non-Hispanic whites, $30.4 \%$ in Hispanic, and $24.0 \%$ in APIs. These differences are much smaller than the regional differences indicating that environmental factors are more important than genetic factors. Nevertheless, genetic factors cannot be neglected since this tumor is clearly more common in Hispanics. In all racial groups, the outcome was very poor.

Enteropathy associated T-cell lymphoma (EATL) is associated with celiac disease, but also regularly arise without the patient being known with celiac deisease. In this latter group of patients, one may find intraepithelial lymphocytosis suggesting an undiagnosed celiac disease. Elli et al. [14] used a mathematical model and population-based data on celiac disease and intestinal lymphoma (of all types!). Their model indicates that undiagnosed celiac disease patients have no increased risk for intestinal lymphoma and therefore lymphoma development is not a reason for screening for celiac disease. It is however remarkable that in their series, none of the celiac disease patients had an EATL. The risk for a celiac disease patient to develop EATL is indeed known to be quite low, so more data may be needed to have a firm idea on the risk in case celiac disease is not recognized and thus not treated. Anyway, the main reason for screening is the alleviation of symptoms by diet.

\section{Defining entities}

\section{B-cell lymphomas}

The classification of small B-cell lymphomas with plasma cell differentiation is still sometimes problematic. There are only few positive criteria for nodal marginal zone lymphoma and lymphoplasmatic lymphoma (LPL). Bieliauskas et al. [15] used a clinical feature to approach this problem, namely by collecting 13 cases of gamma heavy chain disease and subsequently studying the pathology. They found that, although the majority of cases represent LPL, several other lymphoma types could be found too. It is therefore clear, that gamma heavy chain disease is a phenomenon that may occur in different types of B-cell lymphoma and does not represent an entity or a criterion for an entity. 
Variants of mantle cell lymphoma (MCL) may resemble diffuse large B-cell lymphoma (DLBL). Vice versa, rarely DLBL has occasionally cyclinD1 expression, thus the distinction can be problematic in some cases. Hsiao et al. [16] found cyclinD1 expression in three out of 206 consecutive DLBL $(1.5 \%)$, but these three cases were Sox 11 and cyclinD1 translocation negative. Since about $90 \%$ of their MCL are Sox 11 positive and virtually all have a break in the cyclinD1 gene, both tests may be helpful in the separation of MCL from cyclinD1-positive DLBL. Zeng et al. [17] give further data on the value of Sox11 expression in CD5 positive DLBL that are actually MCL. They evaluated SOX11 expression in 140 cases of mature B-NHL, including four cases of suspected blastoid MCL that lacked cyclin D1 expression and eight cases of CD5-positive DLBL. Nuclear expression of SOX11 was found in cyclin D1positive MCL (30/30, $100 \%)$ and in a case of cyclin D1negative MCL with typical morphology. SOX11 was also expressed in BL $(1 / 5,20 \%)$ and lymphoblastic lymphoma (2/3 T-LBLs, 2/2 B-LBLs, overall 4/5, $80 \%$ ), whereas all cases of DLBL (including CD5-positive DLBL) and other small B-NHL were negative. The four suspected cases of blastoid MCL were also SOX11 positive. This confirms that SOX11 nuclear expression was a specific marker for MCL, including cyclin D1-negative MCL with typical morphology. They conclude that the routine use of SOX11 in cases of suspected CD5-positive DLBL might help identify additional cases of cyclin D1-negative blastoid MCL. Both studies give us valuable information for routine practice, but we need to keep in mind that classification schemes are made to categorize the bewildering heterogeneity that nature and especially cancer has. In fact, we need to accept that not all lymphomas fit into our schemes, a notion that makes hematopathology so challenging and actually fun to do.

In one of the previous reviews, I described how fast a new method to define a disease can be found, namely the BRAF V600E mutation in hairy cell leukemia (HCL). Rarely, B-cell neoplasias have this translocation, but virtually all HCL cases are positive. As pathologists, we like, however, immunohistochemical markers, although this technique is more prone to mistakes and more expensive than PCR. Andrulis et al. [18] used an antibody against the mutated BRAF protein and confirmed that all their $52 \mathrm{HCL}$ cases were positive, but only one out of 258 other B-cell neoplasias, including HCLmimics, was positive. This was a chronic lymphocytic leukemia (CLL) case which also carried the mutation. The authors conclude that this immunohistochemistry is a reliable method, which is indeed what their data show. They also suggest that this test is helpful in cases with low tumor cell load, but it must be noted that in general PCR is much more sensitive than immunohistochemistry.

The diagnosis of extranodal MALT-L is generally not too difficult, since the biopsies come from extranodal tissues where typical nodal mimics like FL are rare. Nodal MZL, however, is sometimes impossible to separate from FL due to the lack of a positive marker. Falini et al. [19] used their antibody against IRTA1, which recognizes normal marginal zone B-lymphocytes, on a huge amount of lymphomas. Out of 2,104 lymphomas, only MZL cases were positive: $93 \%$ of the extranodal and $73 \%$ of the nodal cases. Using double staining with bcl-6, they were able to show that nodal MZL cells acquire bcl6 at follicular colonization. When confirmed, this marker is valuable addition to the armatorium of antibodies we use in routine practice.

Kominato et al. [20] analyzed the rare thymic MALT-L for chromosomal translocations that occur in MALT-L arising at other sites. They studied 14 cases, found some trisomies 3 and 8 , which are rather unspecific, but no translocations of breaks, very similar to the results known from MALT-L in the thyroid and salivary gland.

Since more than 10 years, we know that DLBL can be divided into major groups, the germinal center (GC-) and the activated B (a-). There are quite some immunohistochemical algorithms that aim at separating these two groups, since expression profiling is not a good technique to identify individual cases. Gualco et al. [21] compared three commonly used algorithms and added another antibody, HGAL, to them. They analyzed 424 cases and found that adding HGAL results in more cases of GC-DLBL, but because they could not compare their results with expression profiling it is not clear whether this is really an improvement.

Another immunohistochemical method to replace a molecular test is the development of a reliable c-MYC antibody. According to Green et al. [22], based on their study of 219 DLBL and BL immunohistochemistry, c-MYC is quite reliable: more than $90 \%$ of the cases with a c-MYC break had more than $80 \%$ nuclear stained cells, whereas less than $3 \%$ of the cases without a c-MYC break was positive. Kluk et al. [23] performed a similar study, but in only 77 cases. They used $50 \%$ stained cells as a cutoff, by which all the cMYC-rearranged cases were positive. These results are quite promising although the precise criteria need to be determined.

\section{T-cell lymphomas}

EN-NK/T-L is defined by the morphology, immunophenotype, and the presence of EBV. They may be of NK or T-cell origin but the type of T-cell receptor is not taken into account. Pongpruttiman et al. [24] show that the proportion of phenotypical T-cell cases in Thailand is about $11 \%$ and that these cases can be $\alpha \beta, \gamma \delta$, and $\alpha \beta / \gamma \delta$. However, the distinction with NK types is not so sharp since these may have in addition rearranged T-cell receptor genes. Their series also confirms the poor prognosis. According to Lin et al. [25], intramucosal cases do much better and that there 
seems to be some association between invasive growth and loss of ETS1.

\section{Cutaneous lymphomas}

The classification of cutaneous lymphoma is more than that of most other types of lymphoma for a main part based on clinical features, which has resulted in a separate classification for cutaneous B-cell lymphomas. This was finally accepted in the latest WHO classification; but now, Aigner et al. [26] bring the ideas developed for cutaneous lymphomas a bit further by comparing cutaneous DLBL with other ENDLBL. Based on morphology (many large centrocytes), immunophenotype (expression of bcl6 but no bcl2 and CD10), and clinical features (young patients, low stage), they propose that a subset EN-DLBL outside the skin fit into the concept of cutaneous follicle center cell lymphoma. If confirmed, indeed there may be more similarities between skin lymphomas and those arising in other extranodal sites, but whether they are follicle center origin or maybe marginal zone remains to be determined. But there is more to site. We know for a long time that mediastinal DLBL has very specific features. According to de Leval et al. [27], DLBL lymphomas of Waldeyer's ring also have specific features: low stage, bcl2 expression in $55 \%$, rare rearrangements of bcl2, and good outcome. Thus, overlap and difference with the work form Aigner: refinement of our classification schemes is an ongoing process.

\section{New entities/subtypes}

Almost all of the literature reviews I have done so far included articles on IgG4-related disease, but I must admit that I am still not sure what this disease really is and also which pathological criteria are relevant. Go et al. [28] tried to put IgG4-related disease into context, by comparing 14 ocular cases with other inflammatory conditions $(n=12)$ and with nine EN-MZL which they consider challenging differential diagnosis. A bit surprising to me, since EN-MZL are to me very different, but that may be my lack of experience with IgG4 disease. They find that the number of IgG4positive plasma cells is higher in IgG4-related disease lesions (could that have been a criterion for the diagnosis in the first place?), and there were also more regulatory Tcells; there were cases with light chain restriction, but no case had a chromosomal aberration that is common in ENMZL, including trisomy 3 . So, we have another small piece of the puzzle.

After the EAHP meeting in Uppsala, there were many questions answered but also open on "early lesions", the topic of that meeting. Important data come from Adam et al. [29] who undertook a large study into the incidence of in situ MCL. They stained, in a 3-month period, all their lymph nodes sampled from solid tumor cases $(1,292$ in 131 patients). They also stained tissues from MCL that were obtained before the diagnosis was made. None of the lymph nodes retrieved for staging contained cyclinD1 positive cells, but in 10 out 37 patients with MCL from whom they had tissue to evaluate they found an early lesions. This is a much lower incidence compared to FL and this fits with the fact that in normal individuals $t(11 ; 14)$ positive cells are much rarer than $t(14 ; 18)$ positive cells, and also that MZL is much rarer than FL.

Clinical features are relevant for classification indeed. Young and elderly persons, with a similar pathology of the lymphoma, have different outcome. Is that only the age, or is there more? According to Deffenbacher et al. [30] and Klapper et al. [31], the genomic profile of mature B-cell lymphomas in children is different compared to adults, but there is overlap. They both suggest that genomic alterations rather than age should determine the treatment approach. This seems a sensible approach, even when age and genomic alterations correlate. One genomic alteration that is found in pediatric B-cell lymphoma is the $t(14 ; 16)$, but since only two cases are described more data are needed [32].

In the elderly (i.e., patients older than the pathologist who makes the diagnosis), EBV is sometimes present in the tumor cells. This has attracted quite some attention and Monte-Moreno et al. [33] add valuable information: these lesions are aggressive and have nf-kappaB activation. Their series of 47 cases is an interesting one: it includes HL and polymorphic cases, so this series is very different from others. Furthermore, 24 of their cases had a T-cell receptor clonality (indicating a problem with the immune system?) and only $64 \%$ had B-cell clonality (indicating a problem with their methodology?). EBV-positive lesions in elderly are a condition that is not yet fully understood.

Kato et al. [34] had 26 cases of EBV-positive cytotoxic nodal peripheral T-cell lymphomas that are CD8 positive and CD56 negative and had less cutaneous involvement than EN-NK/T-L. Presently, this seems not enough to make it a new entity, which the authors suggest.

Another lesion that has a lot of attention lately: so-called double-hit lymphomas. Pederson et al. [35] describe their experience with lymphomas that have both a BCL2 and a MYC translocation. These cases represent about $11 \%$ of their aggressive B-cell lymphomas. These cases were all of the aB-cel-type, most were BL. Only in case the MYC break was the result of a $t(8 ; 14)$ and the prognosis was worse compared to the whole group.

As mentioned before, the number of cutaneous lymphoma entities is quite large, but Battistella et al. [36] indicate they have enough arguments to propose a new entity: primary cutaneous follicular helper T-cell lymphoma (FHTL). They describe five such cases that share expression of 
follicular helper T-cell antigens (CD10, PD-1, Bcl-6, CXCL13) and cutaneous presentation. They have similarities with the recently described nodal cases of FHTL, which are characterized by a somewhat nodular growth pattern, numerous B-cells and some overlap with AILT. The mean age of the five patients was 61 , the lesions were mainly located on the trunk and the head and there was no nodal involvement. Three of the cases had originally been diagnosed as B-cell lymphoma, because of the many B-cells and CD10 expression. Four of the patients developed systemic disease and did not respond well to therapy. Obviously, more cases are needed to decide whether this is indeed a new entity, or that the spectrum of FHLT encompasses both nodal and extranodal manifestations.

\section{Pitfalls in lymphoma diagnosis}

A very well-known pitfall is a biopsy taken from a patient with infectious mononucleosis. But knowing about a pitfall is not sufficient, good criteria are crucial. Louissaint et al. [37] indicate, based on 18 cases of acute EBV infection but with pathological suspicion for lymphoma, that an atypical infiltrate in which large B-cells are MUM1 positive, but CD10 and bc16 negative is likely to reactive. Clinical data, including serology, remain, however, the determining factor.

CyclinD1 is a good marker for MCL, but not entirely specific. In some cases of CLL/small lymphocytic lymphoma (SLL), the proliferation centers stain, generally weaker than in MCL. Gradowski et al. [38] found this in $20 \%$ of their 57 extramedullary cases, but there was no cyclinD1 translocation or Sox11 expression. Awareness of this phenomenon should avoid a wrong diagnosis of MCL in such cases.

\section{Prognostic factors in lymphoma}

As I wrote in the "Introduction", macrophages and other cells from the tumor microenvironment receive renewed attention lately after confirmation that a high number of macrophages in HL lymphoma indicates poor outcome. According to Deau et al. [39], this is especially related to primary refractoriness for therapy, based on 18 cases and 41 controls. Barros et al. [40] show in 100 cases of HL that in patients younger than 10 years of age the number of macrophages is higher and related to EBV positivity. Xu et al. [41] look at c-Met expression in a Dutch and a German cohort of HL patients ( $n=153$ in total) and show that absence of $\mathrm{c}-\mathrm{Met}$ correlates strongly with poor prognosis (i.e., only $20 \%$ difference in 5 years freedom of progression, an unusual criterion). Koh et al. [42] combined two known prognostic markers in 312 HL lymphoma patients, determined cutoff by the best receiver operating characteristic curves and show that the ratio of lymphocyte and monocyte count is a better prognosticator than the number of tumor associate macrophages. All in all, these studies help us very little since the numbers are way too small, there are no predefined cutoff or outcome criteria and/or there is no biological hypothesis tested, just to mention three of the most common shortcomings in studies into prognostic factors.

Nygren at al. [43] investigated a population-based cohort of 186 patients with MCL. Nine percent of their patients were defined as having indolent disease based on the fact that they did not require therapy for at least 2 years. These cases had rarely loss of Sox11 and Sox11 had no prognostic impact. This study does help us: the chance that Sox11 loss does indicate indolent MCL, as was suggested by a few small studies, is now very low, and presently this cannot be used as an indicator for wait and see policy. Less helpful is the finding of Iqbal et al. [44] that one can use miRNA profiling to separate MCL from other B-cell lymphomas and that in a group 30 cyclinD1-positive and seven cyclinD1negative cases a specific miRNA profile is associated with proliferation and prognosis.

With new therapies, prognostic impact of markers may completely change. Maeshima et al. [45] looked into 22 known prognostic factors for DLBL and show in a series of 285 patients treated with rituximab that IPI, bcl2, and bcl6 expression retained their prognostic impact; too many factors and too few patients to draw firm conclusions. Perry et al. [46] used data from only 199 patients to build a biological prognostic model using known prognostic markers (SPARC expression, microvascular density and $\mathrm{aB}$ versus GCB type. The lack of a biological meaning and the small numbers make it unlikely that this is going to be useful.

It is a good idea to combine data from the literature by doing a meta-analysis on prognostic factors. Tan et al. [47] hereby confirm that AILT with hyperplastic germinal centers has a better prognosis than other cases, but even the meta-analysis is still based on only 56 cases. Furthermore, the 5 -year survival of more than $80 \%$ in the group with hyperplastic germinal centers raises doubt on whether these are really AILT.

Yu et al. [48] conclude that extra copies of the ALK gene are associated with a better survival in Alk-positive and in Alk-negative ALCL. However, they also describe that this extra copy is found in cases with an extra chromosome 2 and that there is no relation with the expression of the gene.

\section{Staging}

Correct diagnosis and staging are the cornerstone of optimal management of all cancer types, and certainly for HL. Stevens et al. [49] report on a 4-year period in which 125 newly diagnosed HL patients from a defined geographical 
region were centrally seen and all pathology and radiology was reviewed. Pathology showed $4 \%$ major discrepancies, imaging $15 \%$. In total for $19 \%$ of the patients, a different treatment advice was formulated compared to the advice after the initial work-up. This number is quite high of course and one might agree with the conclusion that all HL patients should have central evaluation before the start of their treatment.

\section{Ancillary techniques}

Similar to the use of light chain restriction in B-lymphocytes as indicator for B-cell clonality, T-cell receptor v-beta family analysis can be used as indicator for T-cell clonality. Using flow-cytometry on 30 lymph node biopsies with T-cell lymphoma and 94 control lymph nodes, Salameire et al. [50] found a very high expansion of a certain v-beta family indicates the presence of a lymphoma. Obviously, the amount of neoplastic cells in a sample can be the limiting factor for this technique. Tembhare et al. [51] use the same technique on samples with low amount of tumor cells, like cerebrospinal fluid. In patients from whom the v-family was known from previous biopsies, this method could be used to detect low numbers of neoplastic cells.

The gold standard for clonality testing in lymphocytes is the analysis of the antigen receptor rearrangement. Tapia et al. [52] confirmed data published earlier in the J. Hematopathol [53], namely that using the Biomed-2 assay for B-cell clonality, in up to $25 \%$ of HL cases B-cell clones can be detected, especially when the kappa chain is targeted.

Fujiwara et al. [54] address a difficult issue with respect to clonality, namely skin lesions. They investigated multiple biopsies from patients with cutaneous B-cell lymphoma. It is known that benign cutaneous B-cell lesions may be clonal and the idea has been put forward that in case multiple lesions carry the same clone this is indicative for a lymphoma. Out of their 20 cases of cutaneous B-cell lymphoma, they could find a clone in 19, but on only about half of the cases the same clone was present in the other biopsy. In two out of 12 patients with a benign B-cell lesion, they also found a clone, but there were no multiple biopsies. The data indicate indeed that the same clone at multiple sites indicates the presence of a lymphoma, although apparently patients with a cutaneous B-cell lymphoma may have multiple primaries.

\section{References}

1. Siddon A, Lozovatsky L, Mohamed A, Hudnall SD (2012) Human herpesvirus 6 positive Reed-Sternberg cells in nodular sclerosis Hodgkin lymphoma. Br J Haematol. doi:10.1111/j.13652141.2012.09206.x
2. Xie L, Ushmorov A, Leithäuser F, Guan H, Steidl C, Färbinger J, Pelzer C, Vogel MJ, Maier HJ, Gascoyne RD, Möller P, Wirth T (2012) FOXO1 is a tumor suppressor in classical Hodgkin lymphoma. Blood 119:3503-3511

3. Meadows SA, Vega F, Kashishian A, Johnson D, Diehl V, Miller LL, Younes A, Lannutti BJ (2012) PI3K $\delta$ inhibitor, GS-1101 (CAL-101), attenuates pathway signaling, induces apoptosis, and overcomes signals from the microenvironment in cellular models of Hodgkin lymphoma. Blood 119:1897-1900

4. Guilloton F, Caron G, Ménard C, Pangault C, Amé-Thomas P, Dulong J, De Vos J, Rossille D, Henry C, Lamy T, Fouquet O, Fest T, Tarte K (2012) Mesenchymal stromal cells orchestrate follicular lymphoma cell niche through the CCL2-dependent recruitment and polarization of monocytes. Blood 119:2556-2567

5. Ryan RJ, Nitta M, Borger D, Zukerberg LR, Ferry JA, Harris NL, Iafrate AJ, Bernstein BE, Sohani AR, Le LP (2011) EZH2 codon 641 mutations are common in BCL2-rearranged germinal center $\mathrm{B}$ cell lymphomas. PLoS One 6:e28585

6. Thorns C, Kuba J, Bernard V, Senft A, Szymczak S, Feller AC, Bernd HW (2012) Deregulation of a distinct set of microRNAs is associated with transformation of gastritis into MALT lymphoma. Virchows Arch 460:371-377

7. Troch M, Kiesewetter B, Dolak W, Jaeger U, Püspök A, Müllauer L, Chott A, Raderer M (2012) Plasmacytic differentiation in MALT lymphomas following treatment with rituximab. Ann Hematol 91:723-728

8. Mannucci S, Luzzi A, Carugi A, Gozzetti A, Lazzi S, Malagnino V, Simmonds M, Cusi MG, Leoncini L, van den Bosch CA, De Falco G (2012) EBV reactivation and chromosomal polysomies: Euphorbia tirucalli as a possible cofactor in endemic Burkitt lymphoma. Adv Hematol 2012:149780

9. Aladily TN, Medeiros LJ, Amin MB, Haideri N, Ye D, Azevedo SJ, Jorgensen JL, de Peralta-Venturina M, Mustafa EB, Young KH, You MJ, Fayad LE, Blenc AM, Miranda RN (2012) Anaplastic large cell lymphoma associated with breast implants: a report of 13 cases. Am J Surg Pathol 36:1000-1008

10. Lechner MG, Megiel C, Church CH, Angell TE, Russell SM, Sevell RB, Jang JK, Brody GS, Epstein AL (2012) Survival signals and targets for therapy in breast implant-associated ALKanaplastic large cell lymphoma. Clin Cancer Res. doi:10.1158/ 1078-0432.CCR-12-0101

11. Wang P, Zhang JD, Wu F, Ye X, Sharon D, Hitt M, McMullen TP, Hegazy SA, Gelebart P, Yang J, Ma Y, Lai R (2012) The expression and oncogenic effects of the embryonic stem cell marker SALL4 in ALK-positive anaplastic large cell lymphoma. Cell Signal 24(10):1955-1963

12. Thakral C, Hutchison RE, Shrimpton A, Barrett D, Laver J, Link M, Halleran DR, Hudson S (2012) ALK+ anaplastic large cell lymphoma exhibits phosphatidylinositol-3 kinase/akt activity with retained but inactivated PTEN-A report from the Children's Oncology Group. Pediatr Blood Cancer 59:440-447

13. Ai WZ, Chang ET, Fish K, Fu K, Weisenburger DD, Keegan TH (2012) Racial patterns of extranodal natural killer/T-cell lymphoma, nasal type, in California: a population-based study. Br J Haematol 156:626-632

14. Elli L, Contiero P, Tagliabue G, Tomba C, Bardella MT (2012) Risk of intestinal lymphoma in undiagnosed coeliac disease: results from a registered population with different coeliac disease prevalence. Dig Liver Dis. doi:10.1016/j.dld.2012.04.020

15. Bieliauskas S, Tubbs RR, Bacon CM, Eshoa C, Foucar K, Gibson SE, Kroft SH, Sohani AR, Swerdlow SH, Cook JR (2012) Gamma heavy-chain disease: defining the spectrum of associated lymphoproliferative disorders through analysis of 13 cases. Am J Surg Pathol 36:534-543

16. Hsiao SC, Cortada IR, Colomo L, Ye H, Liu H, Kuo SY, Lin SH, Chang ST, Kuo TU, Campo E, Chuang SS (2012) SOX11 is useful 
in differentiating cyclin D1-positive diffuse large B-cell lymphoma from mantle cell lymphoma. Histopathology. doi:10.1111/j.136752559.2012.04260.x

17. Zeng W, Fu K, Quintanilla-Fend L, Lim M, Ondrejka S, Hsi ED (2012) Cyclin D1-negative blastoid mantle cell lymphoma identified by SOX11 expression. Am J Surg Pathol 36:214-219

18. Andrulis M, Penzel R, Weichert W, von Deimling A, Capper D (2012) Application of a BRAF V600E mutation-specific antibody for the diagnosis of hairy cell leukemia. Am J Surg Pathol. doi:10.1097/PAS.0b013e3182549b50

19. Falini B, Agostinelli C, Bigerna B, Pucciarini A, Pacini R, Tabarrini A, Falcinelli F, Piccioli M, Paulli M, Gambacorta M, Ponzoni M, Tiacci E, Ascani S, Martelli MP, Favera RD, Stein H, Pileri SA (2012) IRTA1 is selectively expressed in nodal and extranodal marginal zone lymphomas. Histopathology. doi:10.1111/j.1365-2559.2012.04289.x

20. Kominato S, Nakayama T, Sato F, Yamada S, Xia H, Fujiyoshi Y, Hattori H, Inagaki H (2012) Characterization of chromosomal aberrations in thymic MALT lymphoma. Pathol Int 62:93-98

21. Gualco G, Bacchi LM, Domeny-Duarte P, Natkunam Y, Bacchi CE (2012) The contribution of HGAL/GCET2 in immunohistological algorithms: a comparative study in 424 cases of nodal diffuse large B-cell lymphoma. Mod Pathol. doi:10.1038/modpathol.2012.119

22. Green TM, Nielsen O, de Stricker K, Xu-Monette ZY, Young KH, Møller MB (2012) High levels of nuclear MYC protein predict the presence of MYC rearrangement in diffuse large B-cell lymphoma. Am J Surg Pathol 36:612-619

23. Kluk MJ, Chapuy B, Sinha P, Roy A, Dal Cin P, Neuberg DS, Monti S, Pinkus GS, Shipp MA, Rodig SJ (2012) Immunohistochemical detection of MYC-driven diffuse large Bcell lymphomas. PLoS One 7:e33813

24. Pongpruttipan T, Sukpanichnant S, Assanasen T, Wannakrairot P, Boonsakan P, Kanoksil W, Kayasut K, Mitarnun W, Khuhapinant A, Bunworasate U, Puavilai T, Bedavanija A, Garcia-Herrera A, Campo E, Cook JR, Choi J, Swerdlow SH (2012) Extranodal NK/ T-cell lymphoma, nasal type, includes cases of natural killer cell and $\alpha \beta, \gamma \delta$, and $\alpha \beta / \gamma \delta$ T-cell origin: a comprehensive clinicopathologic and phenotypic study. Am J Surg Pathol 36:481-499

25. Lin TC, Chen SU, Chen YF, Chang YC, Lin CW (2012) Intramucosal variant of nasal natural killer (NK)/T cell lymphoma has a better survival than does invasive variant: implication on loss of E26 transformation-specific sequence 1 (ETS-1) and T-box expressed in T cells (T-bet) with invasion. Histopathology 60:287-295

26. Aigner F, Korol D, Schmitt AM, Kurrer MO (2012) Extranodal diffuse large B cell lymphoma of cutaneous follicle centre lymphoma type: a study of 24 patients with non-cutaneous primary limited stage extranodal diffuse large B cell lymphoma in support of a new concept. Histopathology 60:774-784

27. de Leval L, Bonnet C, Copie-Bergman C, Seidel L, Baia M, Brière J, Molina TJ, Fabiani B, Petrella T, Bosq J, Gisselbrecht C, Siebert R, Tilly H, Haioun C, Fillet G, Gaulard P (2012) Diffuse large Bcell lymphoma of Waldeyer's ring has distinct clinicopathologic features: a GELA study. Ann Oncol. doi:10.1093/annonc/mds150

28. Go H, Kim JE, Kim YA, Chung HK, Khwarg SI, Kim CW, Jeon YK (2012) Ocular adnexal IgG4-related disease: comparative analysis with mucosa-associated lymphoid tissue lymphoma and other chronic inflammatory conditions. Histopathology 60:296-312

29. Adam P, Schiefer AI, Prill S, Henopp T, Quintanilla-Martínez L, Bösmüller HC, Chott A, Fend F (2012) Incidence of preclinical manifestations of mantle cell lymphoma and mantle cell lymphoma in situ in reactive lymphoid tissues. Mod Pathol. doi:10.1038/ modpathol.2012.117

30. Deffenbacher KE, Iqbal J, Sanger W, Shen Y, Lachel C, Liu Z, Liu Y, Lim MS, Perkins SL, Fu K, Smith L, Lynch J, Staudt LM, Rimsza LM, Jaffe E, Rosenwald A, Ott GK, Delabie J, Campo E, Gascoyne RD, Cairo MS, Weisenburger DD, Greiner TC, Gross
TG, Chan WC (2012) Molecular distinctions between pediatric and adult mature B-cell non-Hodgkin lymphomas identified through genomic profiling. Blood 119:3757-3766

31. Klapper W, Kreuz M, Kohler CW, Burkhardt B, Szczepanowski M, Salaverria I, Hummel M, Loeffler M, Pellissery S, Woessmann W, Schwänen C, Trümper L, Wessendorf S, Spang R, Hasenclever D, Siebert R, Molecular Mechanisms in Malignant Lymphomas Network Project of the Deutsche Krebshilfe (2012) Patient age at diagnosis is associated with the molecular characteristics of diffuse large B-cell lymphoma. Blood 119:1882-1887

32. Salaverria I, Akasaka T, Gesk S, Szczepanowski M, Burkhardt B, Harder L, Damm-Welk C, Oschlies I, Klapper W, Dyer MJ, Siebert $\mathrm{R}$ (2012) The CBFA2T3/ACSF3 locus is recurrently involved in IGH chromosomal translocation $\mathrm{t}(14 ; 16)(\mathrm{q} 32 ; \mathrm{q} 24)$ in pediatric Bcell lymphoma with germinal center phenotype. Genes Chromosomes Cancer 51:338-343

33. Montes-Moreno S, Odqvist L, Diaz-Perez JA, Lopez AB, de Villambrosía SG, Mazorra F, Castillo ME, Lopez M, Pajares R, García JF, Mollejo M, Camacho FI, Ruiz-Marcellán C, Adrados M, Ortiz N, Franco R, Ortiz-Hidalgo C, Suarez-Gauthier A, Young KH, Piris MA (2012) EBV-positive diffuse large B-cell lymphoma of the elderly is an aggressive post-germinal center B-cell neoplasm characterized by prominent nuclear factor-kB activation. Mod Pathol 25:968-982

34. Kato S, Takahashi E, Asano N, Tanaka T, Megahed N, Kinoshita T, Nakamura S (2012) Nodal cytotoxic molecule (CM)-positive Epstein-Barr virus (EBV)-associated peripheral $\mathrm{T}$ cell lymphoma (PTCL): a clinicopathological study of 26 cases. Histopathology. doi:10.1111/j.1365-2559.2012.04199.x

35. Pedersen MØ, Gang AO, Poulsen TS, Knudsen H, Lauritzen AF, Nielsen SL, Gang UO, Nørgaard P (2012) Double-hit BCL2/MYC translocations in a consecutive cohort of patients with large B-cell lymphoma-a single centre's experience. Eur J Haematol 89:63-71

36. Battistella M, Beylot-Barry M, Bachelez H, Rivet J, Vergier B, Bagot M (2011) Primary cutaneous follicular helper T-cell lymphoma: a new subtype of cutaneous T-cell lymphoma reported in a series of 5 cases. Arch Dermatol. doi:10.1001/archdermatol.2011.3269

37. Louissaint A Jr, Ferry JA, Soupir CP, Hasserjian RP, Harris NL, Zukerberg LR (2012) Infectious mononucleosis mimicking lymphoma: distinguishing morphological and immunophenotypic features. Mod Pathol. doi:10.1038/modpathol.2012.70

38. Gradowski JF, Sargent RL, Craig FE, Cieply K, Fuhrer K, Sherer C, Swerdlow SH (2012) Chronic lymphocytic leukemia/small lymphocytic lymphoma with cyclin D1 positive proliferation centers do not have CCND1 translocations or gains and lack SOX11 expression. Am J Clin Pathol 138:132-139

39. Deau B, Bachy E, Ribrag V, Delarue R, Rubio MT, Bosq J, Varet B, Brousse N, Hermine O, Canioni D (2012) Macrophage, mast cell and $\mathrm{T}$ lymphocyte infiltrations are independent predictive biomarkers of primary refractoriness or early relapse in classical Hodgkin lymphoma. Leuk Lymphoma. doi:10.3109/10428194.2012.698274

40. Barros MH, Hassan R, Niedobitek G (2012) Tumor-associated macrophages in pediatric classical Hodgkin lymphoma: association with Epstein-Barr virus, lymphocyte subsets, and prognostic impact. Clin Cancer Res 18:3762-3771

41. Xu C, Plattel W, van den Berg A, Rüther N, Huang X, Wang M, de Jong D, Vos H, van Imhoff G, Viardot A, Möller P, Poppema S, Diepstra A, Visser L (2012) Expression of the c-Met oncogene by tumor cells predicts a favorable outcome in classical Hodgkin's lymphoma. Haematologica 97:572-578

42. Koh YW, Kang HJ, Park C, Yoon DH, Kim S, Suh C, Go H, Kim JE, Kim CW, Huh J (2012) The ratio of the absolute lymphocyte count to the absolute monocyte count is associated with prognosis in Hodgkin's lymphoma: correlation with tumor-associated macrophages. Oncologist 17:871-880 
43. Nygren L, Baumgartner Wennerholm S, Klimkowska M, Christensson B, Kimby E, Sander B (2012) Prognostic role of SOX11 in a population-based cohort of mantle cell lymphoma. Blood 119:4215-4223

44. Iqbal J, Shen Y, Liu Y, Fu K, Jaffe ES, Liu C, Liu Z, Lachel CM, Deffenbacher K, Greiner TC, Vose JM, Bhagavathi S, Staudt LM, Rimsza L, Rosenwald A, Ott G, Delabie J, Campo E, Braziel RM, Cook JR, Tubbs RR, Gascoyne RD, Armitage JO, Weisenburger DD, McKeithan TW, Chan WC (2012) Genome-wide miRNA profiling of mantle cell lymphoma reveals a distinct subgroup with poor prognosis. Blood 119:4939-4948

45. Maeshima AM, Taniguchi H, Fukuhara S, Morikawa N, Munakata W, Maruyama D, Kim SW, Watanabe T, Kobayashi Y, Tobinai K, Tsuda H (2012) Bcl-2, Bcl-6, and IPI are prognostic indicators in patients with DLBCL treated with rituximab-containing chemotherapy. Cancer Sci. doi:10.1111/j.1349-7006.2012.02382.x

46. Perry AM, Cardesa-Salzmann TM, Meyer PN, Colomo L, Smith LM, Fu K, Greiner TC, Delabie J, Gascoyne RD, Rimsza L, Jaffe ES, Ott G, Rosenwald A, Braziel RM, Tubbs R, Cook JR, Staudt LM, Connors JM, Sehn LH, Vose JM, López-Guillermo A, Campo E, Chan WC, Weisenburger DD (2012) A new biological prognostic model based on immunohistochemistry predicts survival in patients with diffuse large B-cell lymphoma. Blood. doi:10.1182/ blood-2012-05-430389

47. Tan LH, Tan SY, Tang T, Lim ST, Tan D, Lim LC, Kam GL, Loh TP, Tao M, Koay ES (2012) Angioimmunoblastic T-cell lymphoma with hyperplastic germinal centres (pattern 1) shows superior survival to patterns 2 and 3: a meta-analysis of 56 cases. Histopathology 60:570585

48. Yu R, Chen G, Zhou C, Gao Z, Shi Y, Shi Y, Zhou X, Xie J, Liu H, Gong L (2012) Extra copies of ALK gene locus is a recurrent genetic aberration and favorable prognostic factor in both ALKpositive and ALK-negative anaplastic large cell lymphomas. Leuk Res 36(9):1141-1146

49. Stevens WB, van Krieken JH, Mus RD, Arens AI, Mattijssen V, Oosterveld M, de Kruijf EJ, de Vries F, Koster A, van der Maazen R, Raemaekers J (2012) Centralised multidisciplinary reevaluation of diagnostic procedures in patients with newly diagnosed Hodgkin lymphoma. Ann Oncol. doi:10.1093/annonc/ mds 201

50. Salameire D, Solly F, Fabre B, Lefebvre C, Chauvet M, Gressin R, Corront B, Ciapa A, Pernollet M, Plumas J, Macintyre E, Callanan MB, Leroux D, Jacob MC (2012) Accurate detection of the tumor clone in peripheral T-cell lymphoma biopsies by flow cytometric analysis of TCR-V $\beta$ repertoire. Mod Pathol. doi:10.1038/ modpathol.2012.74

51. Tembhare P, Yuan CM, Morris JC, Janik JE, Filie AC, StetlerStevenson M (2012) Flow cytometric immunophenotypic assessment of T-cell clonality by $\mathrm{v} \beta$ repertoire analysis in fineneedle aspirates and cerebrospinal fluid. Am J Clin Pathol 137:220-226

52. Tapia G, Sanz C, Mate JL, Muñoz-Mármol AM, Ariza A (2012) Improved clonality detection in Hodgkin lymphoma using the BIOMED-2-based heavy and kappa chain assay: a paraffinembedded tissue study. Histopathology 60:768-773

53. Hebeda KM, Van Altena MC, Rombout P, Van Krieken JH, Groenen PJ (2009) PCR clonality detection in Hodgkin lymphoma. J Hematop 1:34-41

54. Fujiwara M, Morales AV, Seo K, Kim YH, Arber DA, Sundram UN (2012) Clonal identity and differences in primary cutaneous b-cell lymphoma occurring at different sites or time points in the same patient. Am J Dermatopathol. doi:10.1097/DAD.0b013e318255dbae 